\title{
Rabbinic Authority and Personal Freedom in the Modern Age
}

\author{
Avram Israel Reisner and Murray Singerman
}

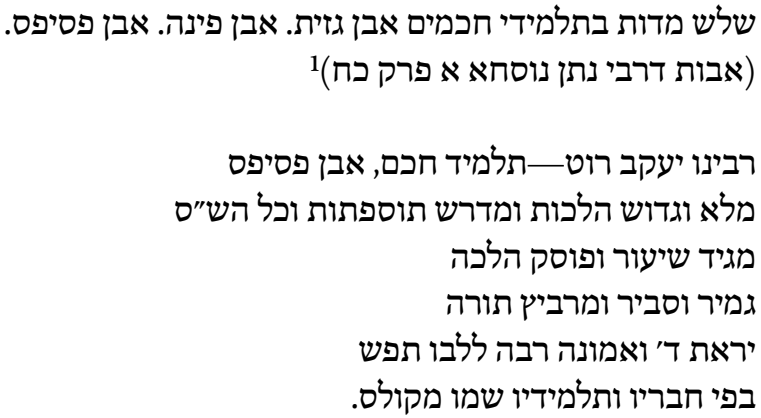

We honor Joel Roth, a decorous sage,

Studied in Jewish law and the Talmud page,

An instructor, a teacher, a master of halakhah,

Learned and wise, always spreading Torah.

His fervor and faith have grown with age.

Students and colleagues speak his praise.

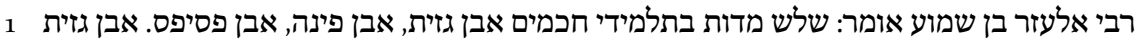

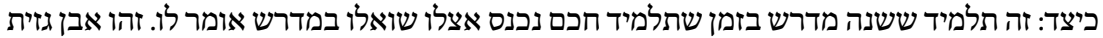

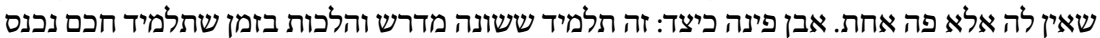

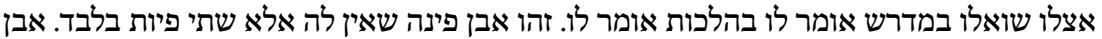

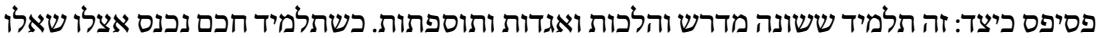

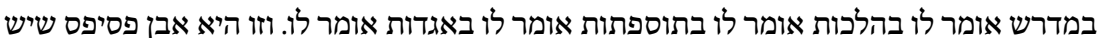

לה ארבע פיות מארבע רוחותיה.

Rabbi Elazar ben Shamua says: There are three types of sages. A hewn stone, a cornerstone and a decorative stone. A hewn stone is a student who, having studied midrash, when he encounters a sage asks questions [to master midrash]. That is a hewn stone. It has only one facet. A cornerstone is a student who, having studied both midrash and halakhah, encounters a sage and asks about both. That is a cornerstone which has just two facets. A decorative stone is a student who, having studied midrash and halakhah, tosefta and aggadah asks of all these. This is a decorative stone, with facets at every side. (Avot of Rabbi Nathan A, 28).

(C) AVRAM ISRAEL REISNER AND MURRAY SINGERMAN, 2021 | DOI:10.1163/9789004420465_012

This is an open access chapter distributed under the terms of the GCBY-NC-ND 4, license. 
For the Jew who integrates halakhah into his or her life, emotionally charged situations bring fundamental intellectual challenges to the forefront, demanding a resolution. Consider, for example, a pregnant woman informed by her doctors that the fetus she carries suffers from anencephaly. Her baby will be born without the frontal lobe and the thinking and coordinating parts of his brain. With no known treatment, this baby will die shortly after birth.

Faced with this problem in a different time and place, observant Jews would turn to their rabbi and seek a ruling on what to do. May-or should-the mother abort, or must she go through pregnancy and labor to give birth to a child who will soon perish, then sit in mourning should the child survive thirty days? To answer this heartrending query, the rabbi would wrestle with the tomes of Jewish tradition and law without involving the parents. Although the rabbi might consider their feelings and ability to bear this tragedy as factors in reaching a decision, the rabbi would not bring the parents into the legal process to weigh and choose between differing legal opinions. The parents' fate as to how to proceed would be dictated by the ruling received from their rabbi, which the parents would willingly obey.

In the democratic West, however, in a society that elevates individuality, initiative and autonomy over willful obedience, tragedies like anencephaly, and even other less trying situations, ${ }^{2}$ raise front and center the conundrum as to what role we as individual Jews play in Jewish decision making. If, as will be argued below, there is no substantive halakhic basis for today's rabbis to exercise their authority through compulsion, what role then, if any, do the feelings, intellect, and autonomy of the Jew play in reaching halakhic decisions? Must we be mute in the face of the determinations of rabbis who interpret and apply halakhah, or can we, and should we, play a role in the legal process and assert our individual inclinations in reaching a P'saq? To answer these weighty questions, this article examines how our Sages - who view themselves as caretakers of our Torah-understood the reach and limits of their ability to compel obedience with their dictates.

2 Among many examples: whether to honor a relative's request to donate his or her body to science; whether to take a business dispute to secular court or only to a bet din; whether to eat in vegan restaurants that lack formal kashrut supervision; whether to permit kitniyot on Pesach given the constriction of various dietary restrictions of members of the family; or simply whether to say "barukh hashem l'olam" at Maariv as do most Ashkenazim in the Diaspora, or not to recite that prayer, as per the GR" A and as has become normative in Israel. 


\section{A Covenant of Consent}

At the outset, we note that the nature of the relationship between God and the Jewish people originated in a brit, a covenant of consenting parties. The Torah's description of Sinai in Exodus 24:73 reflects that enthusiastic consent([Moses] took the record of the covenant and read it before the people, and they said: All that which God has said we shall perform and obey). ${ }^{4}$ Pursuant to that brit, the Jewish people agreed at Sinai and later in the flats of Moab ${ }^{5}$ to be bound.

Laws can be the authoritarian decree of a monarch, as indeed the laws given at Sinai by God might have been viewed. God, however, seeks, throughout the Torah, to gain acceptance as Israel's God (Elohim), ${ }^{6}$ and predicates His calls to obedience upon it. Acceptance requires volition: a brit, a pact or covenant, as is clear from the language of brit used to describe the events both at Sinai and again in the plains of Moab. ${ }^{7}$ Describing the receipt of the Torah as effectuated in a brit entails certain complications. If the Torah is conceived as a contract, a brit, what will bind future generations? This question must be addressed by any system which posits that law rests on the consent of the governed. John Locke argued that it is only by individual consent that a person may subject himself tot the laws of a society in which he chooses to live. How then are those societies perpetuated over time? "Locke's most obvious solution to this problem is

3 All citations of verses from the Bible and of rabbinic passages appear here in our own translation. The Hebrew original of rabbinic passages will be found in the notes.

4 That this was the intent of this verse in the Torah itself seems clear, and rabbinic comments highlighting Israel's merit in willingly accepting God's commands are common. See, for instance, the midrashim of R. Hizkiyah and of R. Simlai on the latter half of b. Šabb. 88a, the comment by R. Joshua that God was pleased by Israel's response in Masekhet Derekh Eretz, Perek haShalom 3, or the well-known midrash from Mekhilta d'R. Ishmael, Yitro, Masekhta D'bahodesh, Parashah 5, that the Torah was offered each of the gentile peoples, but they rejected it, whereas Israel received it with open arms, and many more.

As is often the case in midrash, an alternative view is expressed in b. Šabb. 88a by R. Avdimi bar Hama (on b. 'Abod. Zar. 2b, Dimi) that God threatened Israel with destruction if they did not accept the Torah. R. Aha bar Jacob, however, rejects this, arguing that coercion would undercut the binding claim of the Torah upon Israel (מכאן מודעא רבה לאורייתא). Be this as it may, the $p$ 'shat of the Torah's narrative stands on its own.

5 The alluvial plain east of the Jordan River opposite Jericho, which reaches to the foothills of the mountains of Moab.

6 See, for instance, Exod 6:7, Lev 22:32-33, Num 15:41, Deut 29:9-12.

7 See, for instance, Exod 24:7-8; 34:27-28; Deut 5:2-3; and the verses that are a focus here, Deut 29:9-14. 
his doctrine of tacit consent."8 Individuals functioning within a society without registering objection to its ways implicitly grant tacit consent to those norms.

Moses, in his final speeches in Deuteronomy, proposes more than Locke's implicit consent. He describes a timelessness to Torah which transcends generations. Speaking to the children of the original recipients of the covenant, Moses asserts that, even though many of them had not yet born, they themselves had enacted the covenant at Sinai.

ד'א-להינו כרת עמנו ברית בחרב. לא את אבתינו כרת ד' את הברית הזאת, כי אתנו,

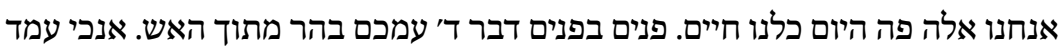
בין ד' וביניכם בעת ההוא להגיד לכם את דבר ד'.

Adonai our God established a covenant [brit] with us at Ḥoreb. It is not with our ancestors [alone] that Adonai established this covenant, but with us, we who are here today, all of us alive today. Adonai spoke to you face to face on the mountain from the midst of the fire while I stood between Adonai and you at that time to convey to you Adonai's word. (Deut 5:2-5)

As is appropriate for a timeless God - the God of creation and of eternity-His brit (covenant) stands across all time, confirmed by explicit consent, even by future unborn generations.

He explains further when speaking to the people of Israel in Moab at the time of the renewal of the covenant:

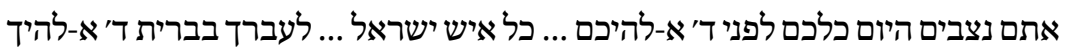

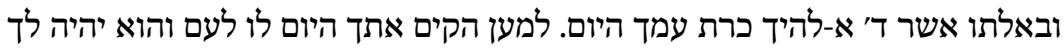

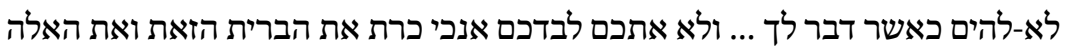
הזאת, כי את אשר ישנו פה עמנו עמד היום לפני ד' א-להינונו ואת אשר הברית איננו פה עמנו האלה

היום.

You stand here today, all of you, before the Lord your God ... every member of Israel, to enter the Lord your God's covenant [brit], and His oath, which the Lord your God establishes with you today in order to constitute you, today, as His people and so that He shall be your God, as He said to you ... It is not with you alone that I establish this covenant and this

8 Stanford Encyclopedia of Philosophy, accessed online at https://plato.stanford.edu/entries/ locke-political/\#ConPolOblEndGov on 11/21/17. 
oath, but [both] with the one who is here standing with us today before the Lord your God, and with the one who is not here with us today. (Deut 29:9-14)

The Sages made clear that the brit applies not just to the second generation under Moses, but is a commitment true for all generations of future members of the Jewish people.

"[Both] with the one who is here standing"-This refers only to those standing at Mount Sinai. Whence do I know [that it includes] future generations and converts who are destined to convert in the future? Scripture teaches: "and with the one who is not [here]." (b. Šebu. 39a)

This midrash is tied to the verses surrounding the second covenant in the plains of Moab, but makes clear that it is speaking about standing at Sinai. ${ }^{10}$ Thus Judaism has always understood that the relationship between God and the Jewish people was one of explicit consent by all generations, a covenant both binding and eternal. ${ }^{11}$

\section{A National Court with the Authority to Compel}

Our Sages saw as well that Moses formulated an approach to addressing another problem of the law — how it should resolve issues that arise after the giving of the covenant, situations that are not spoken of clearly in the covenant's text.

כי את אשר ישנו פה-אין לי אלא אותן העומדין על הר סיני, דורות הבאים וגרים העתידין

להתגייר מנין? ת"ל: ואת אשר אינו פה מינו [פה].

10 See also b. Šabb. 146a. Indeed, the Mishnah's ruling that one cannot make a vow about a clear Toraitic commandment because one is "in a continuing state of commitment ever since Mount Sinai" (מושבע ועומד מהר סיני), which appears many times in the Talmud, owes its formulation to the idea that all Jewish souls, even those not yet born, even those destined to enter Israel through conversion, had stood together at Mount Sinai.

11 In a blog for the Times of Israel published on February 2, 2018, entitled "The bond of loyalty and love," seeking to describe the difference between a contract and a covenant, Rabbi Jonathan Sacks writes: "In a contract, two or more people come together, each pursuing their self-interest, to make a mutually advantageous exchange. In a covenant, two or more people, each respecting the dignity and integrity of the other, come together in a bond of loyalty and trust to do together what neither can achieve alone. It isn't an exchange; it's a moral commitment ... Contracts benefit; covenants transform. Contracts are about "Me" and "You"; covenants are about "Us" ... On Mount Sinai ... the people made with God, not a contract but a covenant." 
In Deuteronomy 17:8-13, Moses foresees the foundation of a national court able to interpret and extend the law, and grants that court the authority to compel. ${ }^{2}$ This power appears to stand in contrast to the consent implied by brit, but Locke, too, understands consent to imply acceptance of obeying the government even in its function as lawgiver and punisher. ${ }^{13}$

Moses describes an authoritative national court associated with God's chosen place, ultimately determined to be the Temple Mount in Jerusalem.

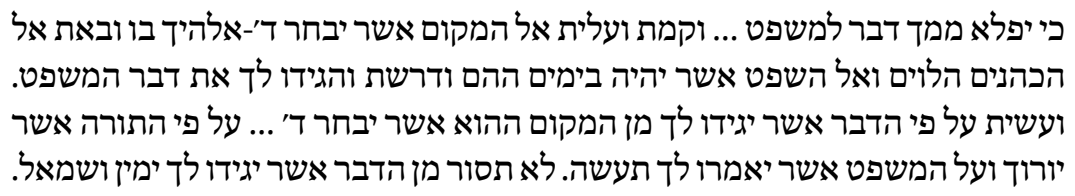

When a matter of judgment escapes you ... you shall go up to that place which Adonai your God has chosen and approach the Levitical priests or the judge who shall exist in those days and seek [counsel in that matter], and they shall tell you [the proper] judgment [in the matter]. And you shall act in accordance with that which they have told you [which emanates] from that place which Adonai has chosen ... You shall act in accordance with the instruction that they teach you and the judgment that they have spoken to you. Do not veer from that which they tell you neither right nor left.

Next, Moses describes the ability of the Court to enforce its decisions through compulsion:

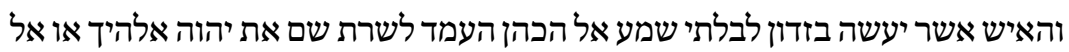

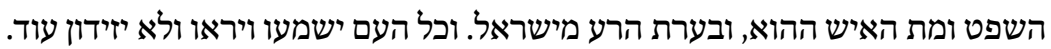

12 This description assumes that Moses intended a national court that would exercise legislative functions, expressed by the phrase כי יפלא ממך דבר למשפט When a matter of judgment escapes you"). That is certainly the assumption of later rabbinic sources. A cogent argument, however, can be made that in the Torah's p'shat the next words (that

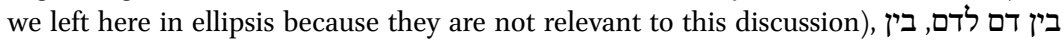
בין דין לדין לין, ובין נגע לנגע, דברי ריבות בשעריך, ("whether a matter of homicide, civil law or torts, matters of dispute in your gates") are intended to define the type of judgment under consideration, which is exclusively judicial and not legislative. In that event the authority even of the Bet Din haGadol would derive from later considerations. Be this as it may, it is clear that the Sages understood the warrant of the High Court in legislative matters to flow from here.

13 See above, n. 8. 
And the man who willfully refuses to heed the Kohen who serves before Adonai your God or to [heed] the judge, this person shall be put to death, and you shall wipe out the evil from your midst. And all the people will hear and see, and they will no longer go astray.

The High Court's location is described in m. Sanh. 11.2, ${ }^{14}$ which details the process to be followed in the case of a sage who holds a contrary opinion and acts upon it, referred to as a זקן ממרא (zaken mamre / rebellious sage) [presented here with an explanatory note by the commentator Ovadiah of Bertinoro]:

[Regarding] a sage who is rebellious against the word of the court, as it says, "When a matter of judgment escapes you": There were three courts there. One sat at the entrance to the Temple Mount, one sat at the entrance to the Temple Court, and one sat in the Chamber of Hewn Stone.

[(Bertinoro): If a certain sage taught in his town and the court in his town differed with his teaching, he and the court of his town] travel to the court that sat at the entrance to the Temple Mount, and he [the sage] says: 'Thus did I expound and thus did my colleagues expound. Thus did I rule and thus did my colleagues rule.' If they [the court that sat at the entrance to the Temple Mount] had a tradition, they would tell them. If they did not, all of them go to the court that sat at the entrance to the Temple Court. He says: 'Thus did I expound and thus did my colleagues expound. Thus did I teach and thus did my colleagues teach.' If they had a tradition, they would tell them. If they did not, all of them go to the High Court that sat in the Chamber of Hewn Stone, from whom the Torah flows to all Israel, as it says, "from that place which Adonai has chosen."

If he returned to his town and studied and taught as he was wont to teach, ${ }^{15}$ he is not liable. But if he ruled that one should act [in contravention of the ruling of the High Court] he is liable.

זקן ממרא על פי בית דין שנאמר (דברים י"ז) כי יפלא ממך דבר למשפט וגוו'. שלשה בתי דינין 14

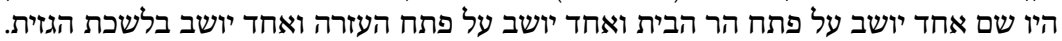

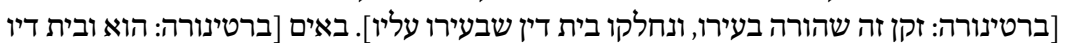

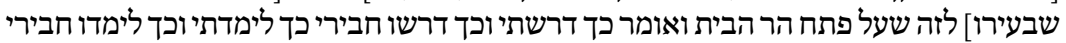

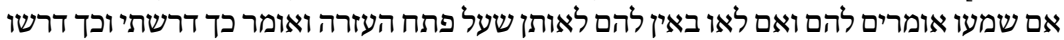

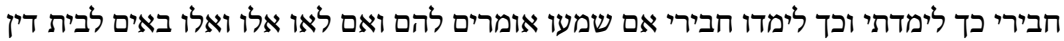

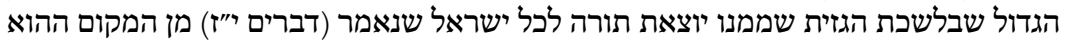

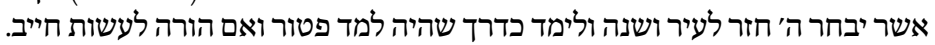
See Sifre to Deut $17: 8$.

15 The Mishnah functions under the assumption that the High Court ruled against him, for otherwise how would he have become a rebellious sage. 
Reinforcing the biblical idea of the centrality of the High Court and its power, b. Sanh. $89 a$ establishes that the rebellious sage must be put to death in the most public of areas and at the most visible of times-before the High Court in Jerusalem during the Festivals, when Jews crowded in to worship in the Temple- underscoring the enormity of the High Court's ability to compel Jews to follow the Sages' interpretations of the Torah.

The storied departure of the Sanhedrin from the Temple Mount to Yavneh in the days before the destruction of the second Temple raised the question as to whether the authority to compel given to the High Court ceases to exist once the Court no longer sits in the Temple. At the heart of this question lies the Torah's repetitive emphasis on the term המקום (hamakom), translated as "the place." The term appears first in Deuteronomy 17:8, instructing the petitioner to go up to hamakom, "the place, which Adonai your God has chosen." One sentence later, God commands us to act in accordance with the High Court's decision, "from the place which Adonai has chosen." The repetition of hamakom is unnecessary because we already know where the decision emanates from, having been told to go up to and seek clarification in that place. We also know that God chose that place. Does the redundant use of the term "hamakom," thereby emphasizing the singular place God has chosen, limit rabbinic authority and the power to compel to the Temple Mount? ${ }^{16}$

\section{Legal Authority After the Destruction of the Temple}

Exercising midrashic artistry, the Sages extended their legal authority even though the location to which it was tied systemically lay in ruins. The High Court's power would continue elsewhere, albeit in a limited manner.

To extend their authority to another place, the Sages limited their judicial power. They determined that the insistence on "the place" in verses 8 and 10, which recognized only the court seated at the Chamber of Hewn Stone as authoritative, applied only to matters of capital punishment, ${ }^{17}$ allowing the High Court to exercise its general authority in a place other than the Temple Mount.

16 In the language of the Bavli (Soțah 45a; Sanh. 14b, 87a; 'Abod. Zar. 8b), מלמד שהמקום גורם, that is, that the emphasis in the biblical dispensation on "the place" teaches that the place has an essential bearing.

Thus in the instant case the rebellious sage could only be put to death if he were rebellious 
With the scope of their authority truncated, the Sages, as recorded in the Sifre, expanded the locus of their judicial seat to include Yavneh, the legendary site of the Sanhedrin from the eve of the destruction of the second Temple until the Bar Kokhba rebellion in $132 \mathrm{CE}$. On verse 8 Sifre states what seems to be the intent of the verse, identifying the Temple Mount, the place chosen by Adonai, as the source from which Torah would emanate. Sifre says of the Chamber of the Hewn Stone that "from there Torah flows to Israel." Yet, in the next verse, Sifre expands the location of judicial authority to include Yavneh by declaring the words, "and you shall approach," to be extraneous and the basis of their midrashic expansion.

ובאת_לרבות בית דין שביבנה

"and [you shall] approach" - this comes to include the [High] Court in Yavneh. (Sifre Deut, Šoftim, ${ }^{\# 153)}$

The midrashic transfer of the High Court's authority from Jerusalem to Yavneh raises significant questions. If hamakom ("the place") of the Temple Mount is no longer required to exercise judicial authority, does the requirement of the High Court fall by the wayside as well? What did the Sages intend by extending the authority of the High Court to Yavneh? Was Yavneh the only place other than the Temple Mount from which the High Court could exercise its authority, or was Yavneh simply the successor of Jerusalem and current seat of the High Court? Could other places become the new seat of judicial authority? Was their intent, perhaps, to extend authority beyond the High Court to any court?

\section{Maimonides' Construct}

In his Mishneh Torah, Maimonides (known as Rambam) appears to claim that the authority of the High Court cannot be exercised in a location other than the Temple Mount. In the chapter concerning those who are rebellious (Hilkhot Mamrim) Rambam opens by specifying that:

against the High Court sitting in the Chamber of Hewn Stone (b. Soțah 45a; b. Sanh. 14b and y. Hor. 1:1 [45d]), and that was the case with regard to all capital punishment (Sifre Shoftim \#154, Midrash Lekah Tov to Deut 17:10). Indeed, it is reported that when they were unwilling to rule in capital cases, the Sanhedrin left the Chamber of Hewn Stone so as not to be called upon to do so (b. 'Abod. Zar. 8b). 


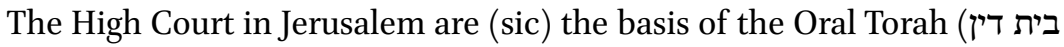
(הגדול שבירושלים הם עיקר תורה שבעל פה (ה) They are the pillars of instruction from whom law and judgment flow to all Israel, and it is upon them that the Torah relied, saying "in accordance with the instruction that they teach you" - this is a positive commandment. Whoever believes in Moses our teacher and his Torah is required to base religious activities upon them and rely on them. ${ }^{18}$

This statement of law identifies the High Court as sitting in Jerusalem. However, in his Minyan haMitzvot at the beginning of Mishneh Torah, Mitzvat Aseh \# 174, Maimonides identifies the mitzvah as "to heed any High Court that shall arise in Israel (תעשר) לשמוע מכל בית דין הגדול שיעמדו להם לישראל שנ' ועל המשפט אשר יאמרו לד " תעשה)," restricting this exclusively to a High Court, but without restricting its locus to Jerusalem (or only to Jerusalem and Yavneh). Fleshing this out, Rambam writes in Sefer haMitzvot:

The 174th mitzvah is that [God] commanded us to heed the High Court and do whatever they command in matters of that which is forbidden and that which is permitted. And there is no difference in this regard between a thing ... that they agree is a hidden element of the Torah or an issue that they believe to be proper and a bolstering of the Torah. In every case we are required to heed and do it and to maintain their position and not cease to do it. That is the meaning of His saying, "in accordance with the instruction that they teach you." As the Sifre says: "You shall act in accordance with ... the judgment that they have spoken to you" - this is a positive commandment. ${ }^{19}$

In the sixth chapter of Mishnat Ya'avetz, section 4, Jacob Emden (18th c. Germany) notes the apparent contradiction between Maimonides' statements in

בית דין הגדול שבירושלים הם עיקר תורה שבעל פה, והם עמודי ההוראה ומהם חק ומשפט יוצא 18

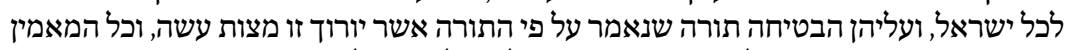
במשה רבינו ובתורתו חייב לסמוך מעשה הדת עליהן ולישען עליהן. Compare Sifre Shoftim \#152-154 of which this appears to be a loose, somewhat expanded reflection.

והמצוה הקע"ד היא שצונו לשמוע לבית דין הגדול ולעשות כל מה שיצוו בו מאיסור והיתר. ואין 19

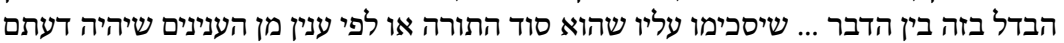
שהוא ישר ושבו חזוק לתורה. הכל אנו חייבים לשמוע אותו ולעשותו ולעמוד על פלי פיהם לא נעבור ממנו. והוא אמרו יתעלה (ר"פ שופטי") על פי התורה אשר יורוך. ולשון ספרי ועל המשפט אשר יאמרו לך תעשה. זו מצות עשה. Both citations are from Deut 17:11. The Sifre referenced is Sifre Shoftim \#154. 
Mishne Torah and Sefer HaMitzvot, and points to what he sees as an intentional midrashic expansion of the law in Sifre \#153 (cited above) as Rambam's source. ${ }^{20}$ Emden, following the Sifre, reconciles Rambam's two statements as allowing the transfer of legal authority beyond the Temple Court. Despite the destruction of the Temple, Jewish religious sovereignty continued, but was limited to the court at Yavneh and its successors - to a High Court, or Sanhedrin, and not to any court. Rambam apparently believed that only such a national court fits the context of this Torah passage and deserves this level of regard. ${ }^{21}$

We should note that the Talmud itself considers whether rabbinic authority has biblical basis. In b. Šabb. 23a (also b. Sukkah 46a), the Babylonian Talmud asks how one could say the blessing "who has sanctified us with His commandments" regarding religious obligations enacted by the Sages such as the lighting of Hanukkah candles. The act does not arise from God's command, since Hanukkah was enacted long after the days of Moses. The Talmud records:

Said Rabbi Hiiyya son of Ashi in the name of Rav: One who lights Hanukkah candles must recite a blessing ... What blessing does he recite? He recites: "who has sanctified us with His commandments by commanding

$20 \quad$ ונראה מקור לדברי הרמב"ם במנין המצוות, דתניא בספרי פרשת שופטים ובאת לרבות בירי"

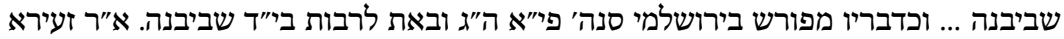

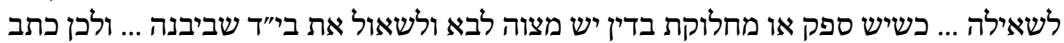

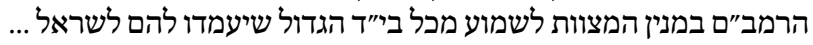

21 Ramban (Nahmanides) rejects this understanding in his comments to Rambam's Mitzvah \# 153, claiming that the authority of the Sanhedrin lapsed when it left its seat in the Chamber of Hewn Stone, and there was no High Court functioning as such in the period thereafter. Emden reconstructs his thinking to match that of Sefer haHinnukh, that the authority that previously resided in the High Court devolved at that point into the more generalized authority claimed by the Hinnukh to be granted to the greatest sage of every generation, but nowhere in his writings that we have been able to find does Ramban address this question of the authority of individual sages absent a national court. More on the thinking of the Hinnukh follows.

Ramban's claim that there was no functioning High Court at Yavneh and thereafter appears gainsaid by the tradition reported on b. Roš Haš. 31a that the Sanhedrin was exiled "from the Chamber of Hewn Stone to Hanut, and from Hanut to Jerusalem, and from Jerusalem to Yavneh, and from Yavneh to Usha, etc.," and by the edicts that are associated with the courts at Yavneh and Usha that have the earmarks of an authoritative national assembly. The old Jewish Encyclopedia entry concerning 'Jabneh' states, "After the destruction of Jerusalem the Great Sanhedrin removed to Jabneh, where it was presided over by Johanan b. Zakkai (R.H. 31a) ... Jabneh took the place of Jerusalem; it became the religious and national center of the Jews; and the most important functions of the Sanhedrin ... were observed there." The newer Encyclopedia Judaica entry on "Sanhedrin" concludes, "After the destruction of the Temple the religious Sanhedrin was reconvened in Jabneh ... When Judea was destroyed ... the Sanhedrin moved to Galilee." 
us to light the Hanukah light." And where did [God] command us? Rav Ivya said: "Do not veer (Deut 17:11)." Rav Nehemiah (other versions: Rav Nahman bar Isaac) says: "Ask your father and he will tell you; your elders and they will speak to you" (Deut 32:7).22

Rav Ivya (in the fourth generation) seems to read Moses' provision for the future, "do not veer," as the source by which to understand the authority of later enactments. His interlocutor avoids that verse, perhaps because he limited its authority to interpretation and not to new enactments. Be this as it may, Emden points out that Maimonides rules expressly in accordance with Rav Ivya in Mishneh Torah, Hilkhot Berakhot 11:3:

All mitzvot that derive from the words of the Sages ... such as reading Megillah and lighting a candle for Shabbat and Hanukkah ..., eruv and handwashing, for each of them, before performing them, one blesses: "who has sanctified us with His commandments by commanding us" to do [the mitzvah]. And where has this been commanded in the Torah? For it is written there: "You shall act in accordance with that ... [which] they have spoken to you". (Deut. 17:11) Thus the meaning of the words, that which they set forth, is: who has sanctified us with His commandments, in which He commanded that we listen to those who have commanded us to light a Hanukkah candle or read the Megillah. ${ }^{23}$

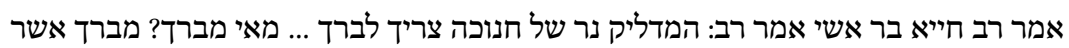

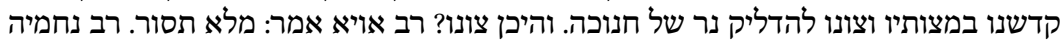

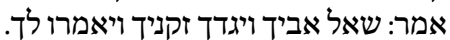

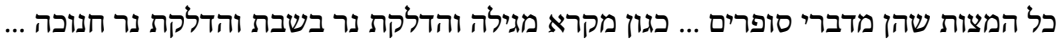

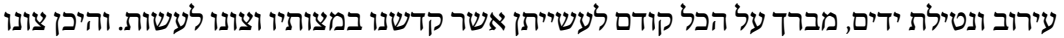

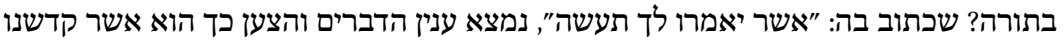

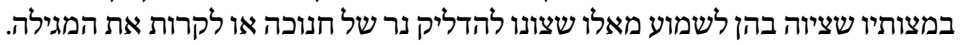
Kesef Mishneh ad locum explains that this is according to the position of Rav Ivya, just citing a different clause from the same verse in order to set out positive language, rather than choosing the negative formulation of lo tasur.

The stance of Rav Nehemiah, here, is unclear. Was he simply proposing a different verse by which to support the use of "who has sanctified us with His commandments by commanding us" (as seems to be the simple reading of the text) or was he objecting to the use of that phrase by arguing that the authority that derives from "do not veer" does not apply to rabbinic decrees, but only the lesser exhortation to heed the sages that might derive from the context of Moses' speech at the end of his life.

A middle ground might be that he was agreeing that a blessing is appropriate, but imagined a more appropriate blessing, see y. Sukkah 3:4 [53d] which considers a berakhah of " $a$ l mitzvat zekenim" (on a commandment of the elders) as a possible blessing in such cases. 
These rabbinic mitzvot, though we do not have a clear history in every case, were clearly arrived at before the time of the Mishnah, a time when the High Court still functioned. ${ }^{24}$

What about legislative authority after the cessation of the High Court?

In several sugyot, the amoraim of the Babylonian Talmud express the notion that the biblical authority granted to the High Court would not apply, but some lesser rabbinic authority would remain.

A sugya in b. Ber. $19 \mathrm{~b}$ rejects the notion that rabbinic rules have biblical authority. The sugya begins by stating that a person's honor cannot override a biblical command because "there is neither wisdom, understanding, nor counsel against the Lord" (Prov 21:30). It then notes two cases where concern for a person's honor seems to allow overriding a biblical prohibition. In each case the Talmud concludes that the infraction that was permitted was not of a biblical rule but of a rabbinic one. Apparently contradicting that conclusion, a baraita is then cited that specifies: "גדול כבוד הבריות שדוחה לא תעשה שבתורה"- - "A person's honor is so great that it overrides a prohibition of the Torah." This baraita, too, is neutralized by Rav bar Shaba (fifth generation), who explains that k'vod habriot overrides only one biblical prohibition, the prohibition of "do not veer." He argues that "do not veer," although it is a biblical prohibition, relates only to the rabbinic proscriptions which follow from it and may be overridden for a person's honor, as in the previous cases. Anonymous students seek to insist that the biblical prohibition of "do not veer" is no less weighty than any other biblical command, but they are shot down by Rav Kahana (also fifth generation), who argues that "they associated all matters of the sages with the prohibition of 'do not veer'” (כל מילי דרבנן אסמכינהו על לאו דלא תסור), though their prohibition remains on the level of a prohibition of the Sages. ${ }^{25}$

24 See Megillah reading - m. Meg. 1:1; Shabbat candle-m. Šabb. 2:1; Ḥanukkah candleBaraita found in b. Šabb. 21 b which includes the schools of Shammai and Hillel, Eruv—m. 'Erub. 1:1; Handwashing-m. Yad. 1:1.

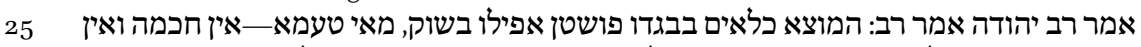

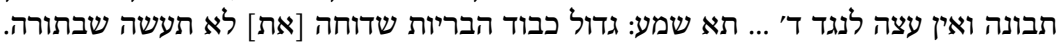

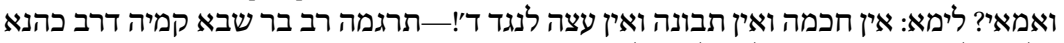

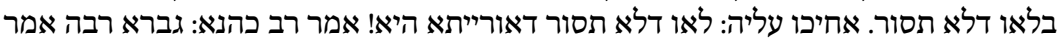

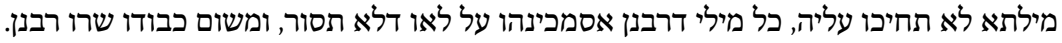

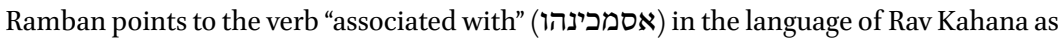
indicating that this was not a true derivation, but simply an exegetical association carrying no legal ramifications. [Comments to Maimonides' Sefer Mitzvot, Shoresh 1]. Be this as it may, the sugya itself indicates that this was his intent, for it is made up of things that appear to be d'oraita and are found to be d'rabbanan, with Rav Kahana's dictum playing the role of downgrading an apparent d'oraita to "just" a d'rabbanan. 
Elsewhere, in b. Hul. 106a, Abaye (fourth generation) justifies reciting a blessing over hand-washing outside the context of Temple purity because "it is a mitzvah to heed the words of the Sages" (מצוה לשמוע דברי חכמים). On its face this appears to give biblical status (mitzvah) to heeding the Sages, but elsewhere Abaye uses the phrase to specifically distinguish a mitzvah of rabbinic provenance from one having biblical status. In b. Yebam. 20a and b. Sanh. 53b he identifies the "shniyot," secondary prohibited relationships, as rabbinically restricted, not biblically restricted, and associates the term "mitzvah" with that status.

The term "mitzvah" also has a softer, non-technical meaning of "appropriate, best practice," as in the dicta in Berakhot, "even if one has recited Sh'ma in the synagogue, it is a mitzvah to read it at bedtime" (בפ על פי שקרא אדם קריאת שמע (בית הכנסת, מצוה לקרותו על מטתו (b. Ber. 4b) and "it is a mitzvah to pray as the light wanes" (מצוה להתפלל עם דמדומי חמה מסת (b. Ber. 29b). The other sage opines

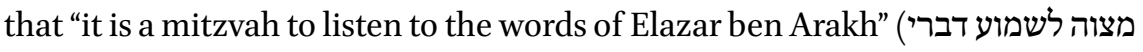
(ר"א בן ערך where the matter of rabbinic or biblical command is not apropos, clearly using the term "mitzvah" to indicate preferable practice. The phrase, "it is a mitzvah to heed the words of the sages," appears again, used in this softer sense, in b. B. Bat. 48a and b. Qidd. 5oa, concerning the coercion of a man into giving a Get. In b. Hor. 2 b fidelity to the "mitzvah to heed the words of the sages" is even judged an error!

In all these cases the biblical injunction is not imputed to the work of the Sages. Indeed, the later anonymous layer of the Talmud uses the phrase "it is a mitzvah to heed the words of the Sages" exclusively in its softer sense, suggesting that, whatever was the case with early rabbinic enactments, to heed the words of the sages was merely considered highly desirable behavior.

\section{Maimonides: Was There a National Court in the Talmudic Period?}

In the Introduction to Mishneh Torah, Maimonides sets forth the devolution of halakhic authority across the ages. In it he expands on the well-known chain of tradition from Sinai to the Mishnah, naming forty links from Sinai through the Mishnah to the completion of the Gemara in the days of Rav Ashi. He stresses that the Gemara includes "things that were newly established by each court, generation after generation, from the time of our Holy Rebbe until the composition of the Gemara," ${ }^{26}$ and he says of these that "it is forbidden to veer from 
them, as it says: 'Do not veer from that which they tell you neither right nor left." ${ }^{27}$ Were the courts throughout the period of the Talmud to be considered High Courts, so as to be granted that authority? Apparently, Maimonides felt that that was the case, for Maimonides writes, "The High Court of Seventy-One became defunct a few years before the composition of the Gemara." ${ }^{28} \mathrm{He}$ explicates that which, in his view, is the virtue of a national court that allows it to continue in place of the High Court in Jerusalem:

Ravina and Rav Ashi and their colleagues are the end of the great sages in Israel who transmitted the Oral Torah; who decreed decrees, enacted enactments and promulgated customs whose edicts, enactments and customs spread to all Israel wherever they were domiciled. After the court of Rav Ashi, who composed the Gemara (finishing it in the days of his son), Israel was dispersed in all lands, an exceeding dispersal ... All those courts that arose after the days of the Gemara in each and every place, who decreed or enacted or promulgated custom for their own constituents, or even for those of many nations - their actions did not spread to all of Israel ... and one does not instruct one court to decree a decree that was decreed by another court in its place ...

But all those things that are in the Babylonian Talmud, all Israel are responsible to follow those ... since all of those things were accepted by all of Israel. ${ }^{29}$

Without granting that the court of Rav Ashi and Ravina was in fact an extension of the High Court of antiquity, one can concede Maimonides' reasoning that a national court, being similar to the High Court in Jerusalem or Yavneh, is empowered by the Torah to interpret the law for all Israel. Such a national mean 'many' or 'several' but the context is one of explaining why the provisions of the Gemara are valid and authoritative upon all Israel, and that seems to suggest that the formal court continued to exist, in the understanding of Rambam, until "a few years before the composition of the Talmud," or even "just a few years."

רבינא ורב אשי וחבריהם סוף גדולי חכמי ישראל המעתיקים תורה שבעל פה. ושגזורו גזירות

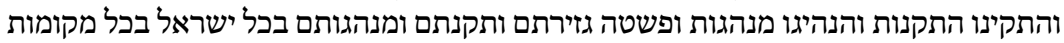

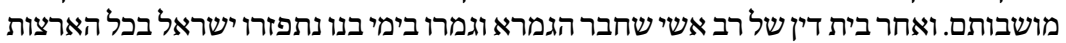

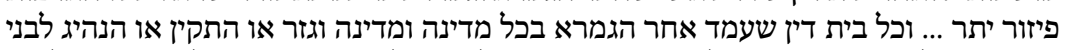

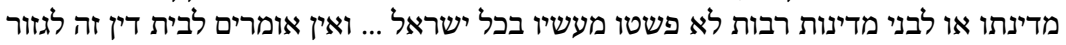

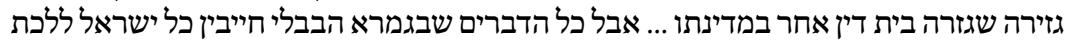
בהם ... הואיל וכל אותם הדברים שבגמרינתו המרא הסכימו עליהם כל ישראל. 
court no longer exists "after the days of the Gemara." According to Rambam, contemporaneous with the redaction of the Talmud, judicial authority and the right to compel as a biblical command ceased.

\section{Sefer haḤinnukh: “The Greatest Sage" Replaces the National Court}

Standing alone among traditional commentaries, the Medieval classic of Jewish thought about the mitzvot known as Sefer haHinnukh ${ }^{30}$ sets forth the broadest biblical basis for rabbinic authority. Hinnukh recognizes the authority of the High Court, yet, even in the absence of that court, he grants biblically commanded authority to the greatest sage in each generation, relying upon a different verse than the verse "do not veer." Addressing this question in Mitzvah \#495, he begins with distinctly Maimonidean language:

To heed the High Court and do whatever they command us with regard to the ways of Torah, that which is forbidden and that which is permitted ...

Having stated the basic mitzvah, he continues to reflect upon it:

What those of blessed memory said, that when the High Court is in Jerusalem, every dispute ... they ask it of the High Court and do as they instruct. Now, when due to our sins there is no High Court there, every dispute that should arise between sages in our generation, if the disputants are equally wise and we are unable to decide among them and do not know how the law should go, if it is a matter of Torah, follow the stringent one; and if a matter of rabbinic law, follow the lenient one ... ${ }^{31}$

Included in this mitzvah is also to heed and act in every age as the judge instructs, that is, the greatest sage who is among us in our time, as those

30 Dating to the middle or late thirteenth century, the author of Sefer haHinnukh remains a matter of speculation. He identifies himself as a Levi from Barcelona, which led to the erroneous attribution to R. Aaron haLevi of Barcelona, who was active at that time, but the author's halakhic positions differ from those or R. Aaron's published texts. It has been argued that, by that measure, he should be seen as a disciple of Rashba (Shimon ben Avraham Aderet, Spain, 1235-1310). In an article in 1980, however, Israel Ta-Shma identifies the author as R. Pinhas, older brother of R. Aaron ("Mehab'ro haAmiti shel Sefer haHinnukh," Kiryat Sefer 55, no. 4 (Elul 5740/ September 1980): 787-79o). That is the opinion, as well, of Charles Wengrov, editor of an edition of Sefer haHiinnukh in 1984.

This refers to a Talmudic principle enunciated in b. 'Abod. Zar. 7a. 
of blessed memory expounded "the judge who shall exist in those days, Jephthah (Yiftah) in his generation is like Samuel in his generation."32

Whoever transgresses this and does not heed the greatest in the wisdom of Torah of that generation in all that they instruct, nullifies this positive commandment, and his punishment is very great, for this is the strong pillar upon which the Torah rests. ${ }^{33}$

According to his presentation, this Torah passage, which dictates and directs how the Torah shall be propagated in future generations, addresses the absence of a High Court. Even though the Sifre limited its extension to the national High Court at Yavneh, and not to any court or sage, the Hinnukh chose to read it as extending the authority broadly to the greatest sage of every generation.

But as creative as the presentation of Sefer haHinnukh is, his Talmudic source in b. Roš Haš. 25a-b does not support his interpretation. To begin, the citation "Jephthah (Yiftah) in his generation is like Samuel in his generation" is not associated with an exposition of the verses in Deuteronomy 17, rather, it is part of a complex of interpretations of Exodus 24:1 asking why the seventy elders of Israel referred to in that verse are not named. The conclusion is that their names are omitted in order to signal that any judge, even a lesser one, should be accepted by litigants, without demanding a judge as eminent as Moses, Aaron or Samuel. This primary teaching is then supported by two additional verses—Deuteronomy 17:8 and Ecclesiastes 7:10. A litigant must accept the ruling of the judge whom he encounters (שופט and not השופט, a judge and not the judge) even if the judge involved is not, as Sefer haHinnukh claims, "the greatest sage who is among us in our time." The discussion neither requires a litigant to seek the "the greatest sage" of the day to interpret religious law nor does it empower each generation's rabbis with the authority and power of the High Court.

32 A conflated reference to a teaching found on b. Roš Haš. 25a-b. See the discussion that follows.

לשמוע בקול בית דין הגדול ולעשות כל מה שיצוו אותנו בדרכי התורה באסור ומותר ....

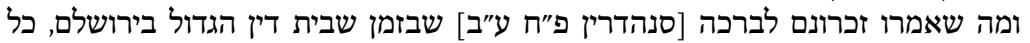

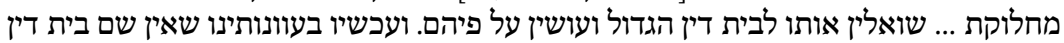

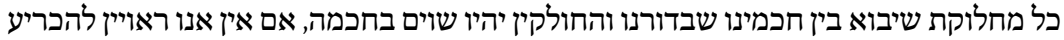

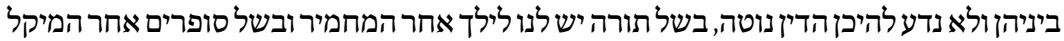

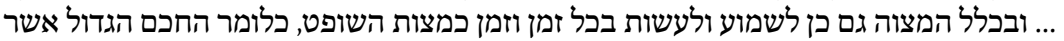

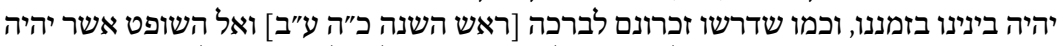

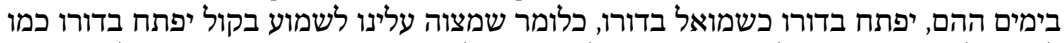

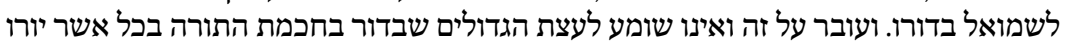

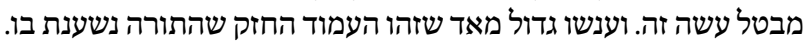


The author of Sefer haHinnukh clearly felt the apparent vacuum of rabbinic authority after the close of the Talmud, but his attempted solution fails, and we could find no other rishonim addressing the question.

\section{The Status of Halakhic Rulings in Our Day}

With the cessation of judicial authority, is there any basis apart from voluntary consent that provides the power of compulsion for rabbis when rendering a decision? After the demise of the Sanhedrin, or after the consensus achieved by the reception of the Talmud, is all judicial authority consensual, requiring the questioner to first obligate himself or herself to the rabbi's authority and then seek his or her teaching, much as participants do in a secular arbitration? And if the questioner desires, may he or she, the one who will live with the outcome of the P'saq, make the final decision based upon the rabbi's guidance and explication of the legal positions and precedent, even if ultimately not following the rabbi's ruling?

Rabbi Tzvi Hirsh Chajes, a nineteeth century Galician Talmudist, ${ }^{34}$ wrote two essays which considered this question: Ma'amar Lo Tasur, the third chapter of the third monograph in his book Torat Neviim, and the longer work Mishpat haHora'ah. He concludes that there is no continuing biblical authority vested in the rabbis of our day. The appearance of halakhic rules preferring the opinion of one sage over another, he says, indeed the very preference for the opinion of the majority over the minority, are, in our day, purely consensual, for all rulings are subject to the arguments even of an individual sage. What is necessary for a binding ruling, and is absent in our day, is an assembly representing the sages of the nation, what we have characterized as a national court, wherein the full spectrum of views is presented for all to consider. In particular he rests on the view expressed by R. Solomon ben Abraham (Rashba) Aderet that "one does not rely on a majority unless that majority arose ... from a give and take of them all."35

Chajes writes:

34 The only classic commentator on the Babylonian Talmud to have earned a PhD in Liberal Arts and Philosophy, as required by the government of Austria of rabbinical candidates in 1846. 
Every sage who in his time and place rules for his people ... according to his reasoning ..., he does not know that another sage has developed through his reasoning ... the opposite of what he has taught, therefore those rules are not obligatory upon us under the biblical command of "do not veer," since the sages differ amongst themselves and we ourselves do not know which one of them should be given priority so that we should listen to him. ${ }^{36}$

Once Chajes clarifies that in the historical period that arose after the sealing of the Talmud (continuing until today) there exists no biblical commandment or later Talmudic ruling to make rabbinic rulings authoritative and compulsory, the final decision how to behave must fall somewhere. If, as we assume, all Jews are מצווים, commanded by God to observe His commandments, then we must find a way to determine how to fulfill those commandments. If there is no rabbinic compulsory authority, then there is no escaping the conclusion that we as individuals, alone, hold the ultimate authority over our own behavior and the final decision (הלכה למעשה). Subtly, though, Chajes betrays he is still looking for authority ("which one should be given priority"), rather than staking out a more radical position such as that held by R. Solomon Luria in the introduction to Yam Shel Shlomo (printed at the front of the second volume).

In introducing Yam Shel Shlomo, composed in Poland in the sixteenth century, Luria notes that Joseph Karo (16th century Spain/Israel), in his introduction to Beit Yosef, explained that he ruled based on the majority opinion of the three primary "pillars of instruction," Rif, Rambam and Rosh. ${ }^{37}$ Luria, however, rejects any appeal to authority after the Talmud, writing:

וכל חכם שבזמנו ובמדינתו מורה לעדתו ... לפי סברתו ... ולא ידע כלל כי חכם אח אחר הוציא

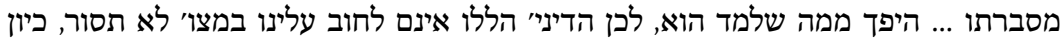

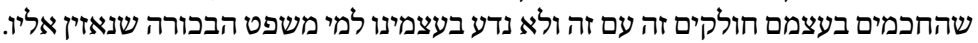
[Torat Nevi'im, Zolkiew edition, 1836, third monograph, p. 12b].

37 Rif $=$ R. Isaac Alfasi, 11th century Algeria; Rambam = R. Moses Maimonides, 12th century Egypt; Rosh = R. Asher ben Yehiel, late 13th / early 14th century Germany and Spain. Realizing that there would be occasions when opinions of all three are not to be discovered, Karo set himself as a tie-breaker a similar preponderance of the opinions of five lesser sages - Ramban, Rashba, Ran, Mordechai and Semag. (Ramban = R. Moses ben Nahman, 13th century Spain; Rashba = R. Solomon ben Avraham Aderet, 13th c. Spain; Ran = R. Nissim ben Reuben Gerondi, 14th century Spain; Mordechai = Mordechai ben Hillel haKohen, 13th century Germany; Semag = Sefer Mitzvot Gadol, a work by Moses ben Jacob of Coucy, 13th century France.) Note that in each case the Sephardic influence outweighs the Ashkenazic. Moses Isserles (16th century Poland) took note of this, and in his introduction to Darkhei Moshe proposed that the source of authority should not be a Sephard-heavy panel, but the greatest and most recent local sage, relying on the principal that the law is best 
Since the days of Ravina and Rav Ashi there is no tradition to rule like one of the geonim or one of the aharonim, rather [we rule according to] whosever's words are deemed appropriate, based on an unambiguous proof according to the Talmud ...

Indeed, Luria continues to excoriate what he saw as the tendency to rule on the basis of people, gedolim, and not on the basis of argumentation.

Even though the generation that came before us, at this moment, in their weakness cannot fathom that any individual great sage (gadol) among the codifiers might err in his understanding, so they imagine that anything written in an ancient text should not be questioned ... Whatever comes from a man's mouth, even though ... his mouth [generally] produces pearls, still we say "a man is a man." Do we not also have, like him, a learned tongue and a reputation in [the study of] Talmud? ... Therefore, I will not believe in any one codifier over another, though there may be a great difference in their stature ... Rather, the Talmud determines. Clear proofs should be dispositive and [be allowed to] give their testimony. ${ }^{38}$

Luria's language is strong, and does not easily apply to those of us who cannot hope to approach his "reputation in [the study of] Talmud," but it does expose the fact, as Chajes did, that substance should prevail. Without the High Court, public acceptance and a great sage's stature alone are not enough to demand compliance, requiring instead substantive proof.

determined by the latest authoritative opinion, that it should be assumed took all the material that preceded it into account (hilkheta k'vatraei). Of course, it is the failure of that global awareness which motivates the critique of Rambam and of Chajes.

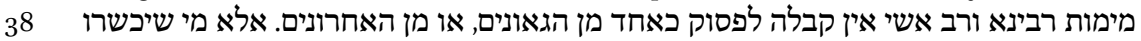

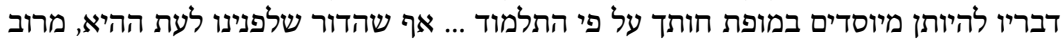

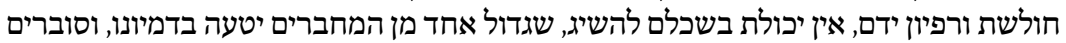

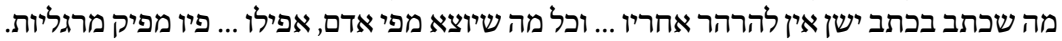

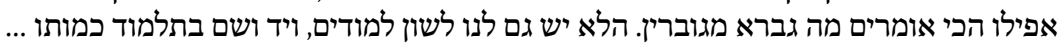

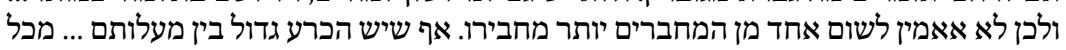
מקום התלמוד הוא המכריע, וראייות ברורות יצדקו ויתנו מחירו. עדיהן. Solomon Luria, Introduction to Yam Shel Shlomo, vol. II. 


\section{Judicial Discretion}

Luria's point is seconded by Dr. Joel Roth in the fourth chapter of Halakhic Process: A Systemic Analysis, titled, "On Judicial Discretion and Precedent." He lifts up a Talmudic dictum, ein lo la-dayyan ella mah she-einav ro'ot (מין לו לדיין אלא —a judge has only that which he sees—as an essential element of post Talmudic halakhic jurisprudence. According to this dictum, no precedent is authoritative, but only serves as guidance for the determination of the current poseq or decisor. Obviously, this strong judicial discretion cannot have been operative when there was a High Court rendering authoritative decisions, but Roth is clear that it was operative in later generations, noting that "only the systemic principle 'ein lo la-dayyan ella mah she-einav ro'ot stands as the ultimate judicial guide".39

Menahem Elon reflects a similar understanding:

In the early period, a final ruling given by the national High Court ... served as authoritative precedent ... [However,] differences of opinion in [matters of] halakhah grew and, over time ... became not just a legitimate phenomenon, but a desirable phenomenon ... The measure which determines and discriminates between opinions in halakhah is the appropriateness of each opinion according to the Talmud that was edited by Rav Ashi and Ravina, based on "an unambiguous proof according to the Talmud ..." That is why Jewish law accepted the principle that 'the law is according to the latter [sages]' ... which comes to assure the freedom of decision to later [decisors]. ${ }^{40}$

Chajes, Luria, Roth, and Elon converge on one point: the radical freedom of the current poseq, the current decisor, to judge in the matter before him or her, but none addresses the question of what grants the poseq the authority to decide for an individual.

39 Joel Roth, The Halakhic Process: A Systemic Analysis (New York: Jewish Theological Seminary, 1986), 113 .

בתקופה הקדומה, פסק דין סופי שניתן על ידי בית הדין הגדול של האומה ... שימש כתקדים

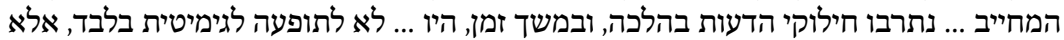

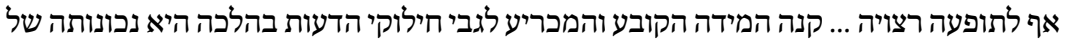

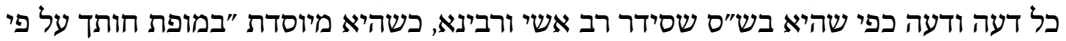

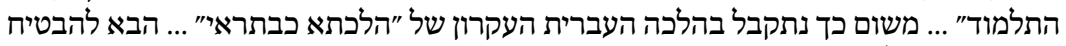

Menahem Elon, HaMishpat haIvri II, p. 8o2, with the internal citation from the Luria passage cited above. 


\section{Rabbi Dikhovsky: Consent Grants Authority}

Rabbi Shlomo Dikhovsky, a member of the Supreme Rabbinical Court of Jerusalem, considered this problem regarding the source of the authority of modern poseqim in an article in the journal K'vodah shel Torah in $1995 .{ }^{41} \mathrm{He}$, too, notes Rambam's inability to extend the chain of authority beyond Ravina and Rav Ashi, and records Chajes' conclusion that indeed there is no such authority in our day; but he is unwilling to concede that conclusion. ${ }^{42}$

Dikhovsky argues that the authority of any court always rested not just on the sage's credentials but on the acceptance by the public of his authority. $\mathrm{He}$ argues that what made a national court, the High Court of antiquity, authoritative was public acceptance, and that is what confirmed the authority of the Talmud. He brings as proof the following Talmudic colloquy from b. Sanh. 14a. When the Talmud reports that R. Judah ben Bava ordained R. Meir, the Talmud asks: “Did R. Judah ben Bava [really] ordain R. Meir? Didn’t Rabbah bar Hannah say in the name of R. Yohanan: Whoever says that R. Meir was not ordained by R. Akiva is mistaken?! R. Akiva ordained him but they [the public] did not accept it. R. Judah ben Bava [subsequently] ordained him and they did accept it." ${ }^{33}$ Public approbation was required for an ordination to be recognized. Dikhovsky argues, therefore, that even though there is no national court after the Talmud and no possibility of rulings for the whole of Israel, local courts continue to exist and to have local authority, because they have the approbation of the local community, even according to Maimonides. Thus, while the specific structure of the Court at the Chamber of Hewn Stone which the Torah foresaw no longer exists, we can extrapolate authority into our own day. ${ }^{44}$

Rabbi Dikhovsky even extends this to the individual, recommending that every person should have a single rabbi whose authority he or she accepts. In this regard he cites a dictum of Avot of Rabbi Nathan:

41 Rabbi Shlomo Dikhovsky, "Hiyyuv haTziyyut L'Hakhmei haTorah b'Yameinu," K'vodah shel Torah (1995), no. 6, pp. 6o-76. חידוש זה הוא מאוד תמוה, כי לדבריו אין מצוה לשמוע דברי חכמים מאז נתבטל בי"ד הגדול. (p.65).

ורבי מאיר, רבי יהודה בן בבא סמכיה? והא אמר רבה בר בר חנה אמר רבי יוחנן: כל האומר רבי ולי

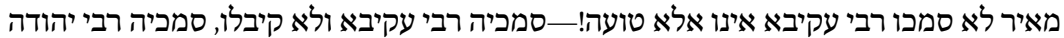

בן בבא-וראוקיבלו.

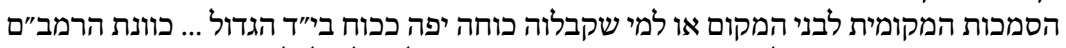

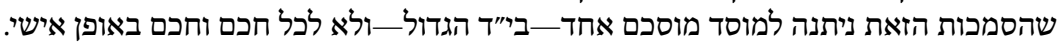

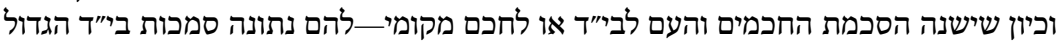
בזה. (Dikhovsky, 65). 
Take a master for yourself- _... Rabbi Meir would say: One who learns Torah from one teacher (rav), to what is he likened? To one who had one field and planted part wheat and part barley, part olive and part [other fruit] trees. That person is replete with goodness and blessing. But when he learns from two or three, he is like one who has many fields, one wheat, one barley, one olives and one trees. That person is scattered among the lands, without goodness or blessing. ${ }^{45}$

Dikhovsky's reliance on Avot of Rabbi Nathan may offer homiletic, but not normative, legal authority. Even more significant is that Rabbi Dikhovsky, seeking a solution with respect to authority, admits there is no textual authority. Everything, even perhaps the very authority of the classic sages after Talmudic times, rests on the consent of the governed. Perhaps this should come as no surprise. The very notion of covenant - of God not wanting to be an autocratic sovereign, but rather wishing to be our God by our assent-suggests that the very structures set up by the Torah to maintain the law should continue to function by our consent. Dikhovsky's argument fails, also, because it is not clear, reading the story as does Rabbi Dikhovsky, that R. Meir received the public's consent for the rabbinic authority of a posek, or simply the approval to be their teacher (hora'ah).

\section{Answering Halakhic Questions Today}

Citing Deuteronomy 14:1, while giving it a midrashic meaning generally understood to be far from its $p$ 'shat, b. Yebam. 13b establishes that communities should not foster internal divisions (לא תתגודדו). Communal harmony, more than anything else, is the justification for the existence of a poseq or a mara d'atra (a local authority). When many autonomous people live together, they must have a procedure of decision for the commons in order to attain unanimity in communal practice.

If, however, we recognize each individual as the locus of autonomy, decisions of individual behavior are not subject to authority. Luria was right, of course, that he had a "reputation in Talmud" and the requisite skill and intellect

45 Avot of Rabbi Nathan A, ch. 8.

עשה לך רב ... היה רבי מאיר אומר הלומד תורה מרב אחד למה הוא דומה לאחד שה שיה ומיה לו שדה

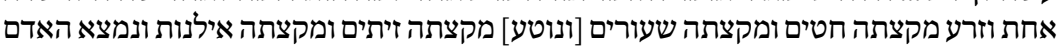

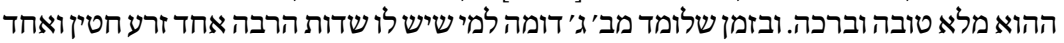

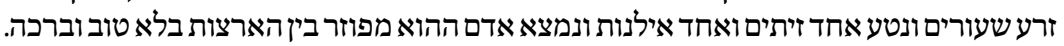


to weigh the options and precedents before him to make an halakhic decision in the matters he faced. He did not need to turn to any other authority except as guideposts. This is not the case for any of us.

For us, poshute yiddin, common Jews, humility recommends we seek our betters in knowledge of Torah to lay out the halakhic debate in order to fully understand what precedent establishes and what options it allows. Setting out that survey should be the role of the rabbi. Then, to the extent that the individual understands the issues and wishes to resolve them within the range of halakhic debate, though not as proposed by a particular rabbinic authority, the individual should possess the prerogative to choose, for it is his or her own religious commitment and articulation in action of which we speak. If we value the religious commitment and intelligence of our laity and recognize their autonomous right of decision, this suggests that rabbis today adopt this new model of dispensing halakhic advice. ${ }^{46}$ As souls who stood with our ancestors at Sinai and freely pledged to observe God's law, we can, each of us, choose to be active partners in the covenant with our God. Just as God chose to offer His covenant to each soul at Sinai, ${ }^{47}$ that offer remains alive for each and every one of us at each and every moment in every act that we undertake.

46 The Committee on Jewish Law and Standards of the Conservative Movement [the Law Committee]'s self-understanding that it is purely an advisory committee within the Rabbinical Assembly, and not a High Court, thus fits well in this model.

47 A well-known midrash asserts that the Revelation at Sinai was tailored to each recipient. It's earliest (and shortest) form appears in Mekhilta d'R. Ishmael, Yitro, Masekhta D’bahodesh, Parashah 9:

וכל העם רואין [את הקולות] ... וכמה קולות היו ... אלא שהיו משמיעים את האדם לפי כחו, שנ' קול ד' בכח (תה' כט, ד).

"All the people saw the voices ..."-How many sounds were there? Rather, [the voices] would teach each person according to his ability [koho], as it says (Ps 29:4): God's voice is powerful [bakoah].

A much longer and more explicit version is found at the end of Pesikta d'Rav Kahana 12:24:

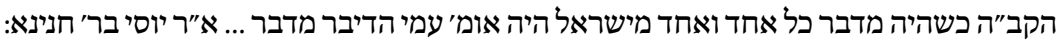

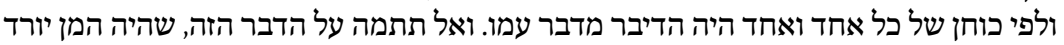

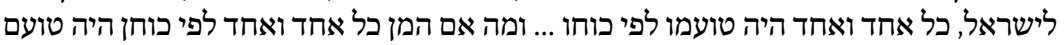

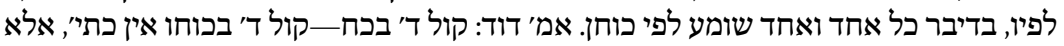
קול ד' בכח, של כל אחד ואד ואחד.

When the Holy One was speaking, each and every person in Israel said: The commandment is spoken to me ... Said R. Yose son of R. Hanina: The commandment would speak to each one according to his ability. Do not be astonished by this, for the manna would fall for Israel, each one according to his taste ... If with regard to the manna, each tasted according to his palate, so with regard to the commandment, each heard according to his ability. Said David: "God's voice is powerful"—it does not say, God's voice exhibits its own quality, rather God's voice exhibits a quality— that of each and every one. 
When congregants seek out a rabbi for personal halakhic guidance, for example the young couple described in the opening of this article, the rabbi should help the parents understand the fundamental halakhah and the sides of debate, then leave it to them to determine their final behavior, rather than present the rabbi's own judicial discretion as the ruling of an authority to whom they are bound. For in the time after the Gemara, when a Jewish High Court no longer exists, all Jews should strive to fulfill the Torah in line with modern notions of autonomy as independent actors serving God as we best understand based upon halakhic options. With the direction and advice of our authorities, every Jew should have the option to take a more active role in fulfilling his or her responsibilities, more engaged in the process of Torah, struggling, if he or she so desires, to reach the right, legal, ethical, and God-affirming decision. God is indeed our God, and we are continually standing at Sinai, and, through our engagement in our own halakhic behavior, we continually show our consent to the Covenant of our Creator.

Rabbi Avram Israel Reisner, a member of the Rabbinical Assembly's Committee of Jewish Law and Standards, is Rabbi Emeritus of Chevrei Tzedek Congregation in Baltimore, MD. Rabbi Murray Singerman, ordained at the Rabbi Isaac Elchanan Theological Seminary of Yeshiva University, served previously as rabbi of Beth Sholom Congregation of Frederick, MD and currently practices law in Maryland.

\section{Bibliography}

Chajes, Tzvi Hirsch. Torat Nevi'im. Zolkiew, 1836.

Elon, Menahem. HaMishpat Halvri. Jerusalem: Magnes Press, 1988.

Dikhovsky, Shlomo. "Hiyyuv haTziyyut L'Hakhmei haTorah b'Yameinu." K'vodah shel Torah 6 (1995): 6o-76.

Roth, Joel. The Halakhic Process: A Systemic Analysis. New York: Jewish Theological Seminary, 1986. 